\title{
Medea or the mother who kills her children: Some aspects regarding family murder
}

\author{
Maria C. Marchetti \\ Department of Psychology \\ Rand Afrikaans University \\ JOHANNESBURG
}

\begin{abstract}
This aricle looks at the phenomenon of the killing of children within the context of family murder. An analysis of the case studies in the Human Sciences Research Council Report on family murder published in 1991 suggests that the parent who carries out the family murder is usually the 'mother' figure of the family. This is also the case when the father is the perpetrator, who is then the parent most emotionally involved with the children.

This phenomenon is examined against the background of other theories regarding the killing of one's children. The case of the mythological figure Medea, a mother who also took the life of her children, is also analysed.

It is suggested that the underlying cause of a parent killing his or her children is a distorted perception of motherhood. This perception causes the 'mother' to take the nururing aspects associated with motherhood to an absurd extreme which is totally out of touch with reality and could be termed as a kind of 'deluded molhemood'. This phenomenon is discussed within the context of disturbed family relationships indicating how differemt interacting factors lead to the destruction of the family system.
\end{abstract}

\author{
How then can these holy rivers \\ Or this holy land love you, \\ Or the city find you a home \\ You, who will kill your children, \\ You, not pure with the rest?
}

(Euripides, Medea:846-850)

\section{INTRODUCTION}

The reasons behind the phenomenon of family murder are extremely hard to establish. It still remains a puzzle why someone would destroy his or her own entire family and end up killing himself or herself. When faced with this tragic phenomenon professionals are often faced with many questions which unfortunately often escape an 
answer. What happens to transform the secure and safe haven of family life into the scene of such a violent act?

One of the most emotionally laden issues surrounding this phenomenon concerns the killing of the children. How can a parent ever bring himself or herself to kill his or her children? How can a woman end the life of the children she has borne or a man kill the children he has fathered?

Even more disturbing is the fact that these children whose parents may be on the verge of family murder are probably unaware of the impending danger, and will naturally trust that their parent(s) will always protect and safeguard them against danger of any kind. These children seldom realise that the greatest danger lies within the very people they trust most.

Because of the great emotionality connected with this aspect of family murder, it will be attempted to look specifically at the killing of the children within the context of family murder. An attempt will also be made to link the results of the research project on family murder carried out by the HSRC and the relevant corresponding elements in the myth of Medea. This parallel will be drawn to stress specific aspects generally associated with the killing of one's children within the context of family murder.

Certain aspects central to this discussion will be examined in detail, namely:

* The specific phenomenon which seems to emerge from the HSRC research results, is that it is the 'mother figure' who usually commits the family murder. This is also true of the case where the father is the perpetrator, as in most of these instances he is the parent most emotionally involved with the children, in other words, fulfilling the role of 'the mother' of the children. (These data were gained after the case studies incorporated in the report of the HRSC (1991) had been analysed.)

- The second aspect to be examined is that the phenomenon of a mother killing her children is not perhaps as new or unique to our social and cultural contexts as the recent media coverage of family murder leads us to believe. Realising that family murder is an age old problem, one is unvoluntarily reminded of the versions of the myth of Medea by two classical writers, the Greek Euripides and the Roman Seneca. As these two versions also represent an underlying attempt to analyse the motivation behind the killing of one's children, a closer examination of these representations might illuminate the underlying motives behind the action of family murder. 
- Finally an attempt will be made to describe this specific phenomenon of the 'mother' figure killing the children in the light of some theoretical considerations.

\section{THE KII IING OF CHIIDREN IN THE CONTEXT OF FAMILY MURDER}

The Human Sciences Research Council report on family murder represents the first all-encompassing attempt in South Aftica to incorporate different views on the subject as well as being the first research project to explore this phenomenon. Until then much had been written on family murder, but the literature merely reflected speculations and ideas about the phenomenon (Marchetti et al., 1992) rather than actual research.

It was thus decided to examine the eleven case studies described in the HSRC report because, "the study can lay claim to a relatively extensive study of a number of authentic cases of family murder " (Olivier et al., 1991:93).

The information contained in this report was gathered by means of structured and open ended interviews from people who were involved with the murdered family, for example friends, relatives, neighbours, work colleagues and so forth. The police and medical people involved were also interviewed. Research teams consisted of at least three members who interviewed the people mentioned above and information had to be validated by this research team afterwards.

The researchers had to take into account the fact that the information gained from the people interviewed was in fact subjective as well as strongly contaminated by extreme feelings of guilt, anger and pain. It was then attempted to identify similarities and common elements so that recurring patterns which led to the occurrence of family murder could be identified (Beyers et al., 1992).

The HSRC report defined family murder as, "the deliberate extermination of the existing system by a member of the family or the intention to exterminate the system" (Olivier et al., 1991:71). The threat to, or the actual killing of the children is thus an inherent part of the family murder.

For the purpose of this article the specific phenomenon under discussion will be defined as (a type of) "filicide" (namely the killing of a child by a parent) (Resnick, $1969)$ within the context of family murder. 


\subsection{Resnick's (1969) filicide classification}

In the course of an extensive literature study carried out as part of the HSRC project, attention was given to both local and overseas literature. Little was found on the specific phenomenon of family murder as defined above, but some literature on different types of killings within the family context is available. The work of Resnick (1969) provides one with an appropriate classification system for different types of filicide. This can also provide researchers with a guideline for further discussion.

Resnick (1969) differentiates between different types of filicides based on the parent's motivations, namely,

\subsubsection{Altruistic filicide}

The motivation here is love and can be further divided into

- filicide associated with suicide, and

- filicide to relieve suffering.

The first example refers to the parents' claim that it would be impossible for them to abandon their children after killing themselves. This refers, therefore, to a kind of extended suicide which is an idea shared by Van Arkel $(1985,1988)$ who sees family murder as a rescue action, whereby the family murderer romanticizes death as a better option to life, and sees death as a better option for the family including the children. In the second example, children are killed by their parents in order to be relieved of their perceived suffering (a form of euthanasia).

\subsubsection{Acutely psychotic filicide}

This category refers to parents who kill their children while suffering from hallucinations, epilepsy or delirium.

\subsection{Unwanted-child filicide}

In this case children are killed because they are no longer wanted by the parents. 


\subsubsection{Accidental filicide}

The parent in this case does not intend to kill the child, but this happens accidentally, for example in the case of child battering.

\subsubsection{Spouse revenge filicide}

This category refers to parents who kill their children in a deliberate attempt to make their spouses suffer.

It is felt that in the case of family murder, Resnick's (1969) categories of specific relevance are the altruistic filicide category, especially the subcategory filicide associated with suicide, as well as the spouse revenge filicide category.

The way in which these two categories are relevant to the phenomenon of the 'mother' killing the children will be explored in the rest of the article.

\section{THE 'MOTHER' FIGURE WHO KILLS THE CHILDREN}

The mother figure in history, whether it be religious (such as Mary), or traditional, has always been perceived as the most emotionally supportive parent, namely 'the nurturer'. The father, on the other hand, has traditionally been perceived as the breadwinner and more concerned with the financial or physical protection of the family.

However today, women are no longer restricted to being merely child bearers and home keepers. In addition to this they often have a full-time job where they compete with men. This new situation is often experienced with discomfort by men who have to deal with a new kind of woman. Relationships and gender roles have changed, and today men are expected to participate in household activities which may include looking after the children.

Therefore one can argue that the changes in traditional gender roles have caused a number of far-reaching social and psychological consequences. It is, however, important to look briefly at some of the implications of these changes.

As the woman moves out into the job market, she devotes less time to her nurturing role and hence a number of things can happen. Either the care of the children is left to members of the extended family or to outsiders, such as domestic servants, or the father is forced to take on the 'nurturing' role. The latter can lead to a situation where 
the nurturing and upbringing of the children is reserved to the father, who then can become the 'mother' figure in the family, as the woman becomes more and more disinterested in her traditional nurturing role.

The process discussed above seems to have taken place in a number of the cases studied in the HSRC Report where the man (who was the nurturing figure) was the murderer, and examples to support this hypothesis will be discussed in more detail.

Out of the eleven case studies in the HSRC report nine of the murders were committed by men, and at least five of these men were described as being closer to the children than the mothers. The results of the Professional Persons' Survey, which also formed part of the HSRC research, also indicate that in the larger percentage of the cases where the father was the perpetrator, he was more emotionally involved with the children than the mother.

All the information which follows is based on comments made by people close to the murdered family who were interviewed in the course of the HSRC research.

\section{Example no 1}

People interviewed about the motivation of the murderer stated that he killed the children "in order to keep them to himself " (Olivier et al., 1991:186). It was also noticed that the murderer was a very possessive person, and although life with his wife had become unbearable, he was not prepared to relinquish his children. Prior to the murder, his wife had left him and taken the children for a long period of time, "which had left him very distressed" (Olivier et al., 1991:186).

\section{Example no 2}

Observers mentioned that the father (who was also the murderer) mainly looked after the children with the help of a maid. He also seemed more emotionally involved with them than his wife who was a career woman. He organized the household matters and even bought clothes for the children. The father-children relationship was seen as the strongest one in the family.

\section{Example no 3}

The mother of the murderer stated that the spouse was neglecting her role as mother and wife: "Sy is net 'n skooljuffrou and hy is die moeder," (She is just a schoolteacher and he is the mother) (Olivier et al., 1991:189). The sister of the murderer stated that her brother had been a caring father who was almost too 
good to his children and too fond of them.

\section{Example no 4}

The murderer was described as having a good relationship with his son and of mothering the child. The spouse also provided for the needs of the child but did not have a close relationship with the child.

\section{Example no 5}

Although information here is more vague it appears as if the children were very important to the murderer. He was described as being closer to his daughter than his spouse. He seemed to have had certain high expectations of his son and was disappointed in him for not being able to play rugby, and other things he expected a boy to do.

Looking at these examples it appears as if the murderer had a very strong emotional bond with the children - a bond which often just differed in intensity.

In case study 2, 3 and 4 three examples are offered where the father seems to take over the mothering role almost completely, while the wife is more interested in outside activities. One also gets the impression that a feeling of overpossessiveness existed in two of the cases ("he was almost too fond of them"; "he was not prepared to relinquish his children.") It can be argued that in the cases where the father took over the mothering role, he was not convinced that the mother could adequately look after the children if he should die, probably because she had never done so in the past. The sense of overpossessiveness also creates a sense of, the children are actually mine and nobody else is going to get them'. This type of idea seems to be shared by De Jongh van Arkel (1985) who refers to the general Christian belief of mutual responsibility and the right to take decisions on behalf of others. He argues that this feeling of responsibility may lead to an authoritarian inequality in the family (which he calls a scriptural misinterpretation).

It can thus be concluded that there seems to be a tendency with the fathers (who are the murderers) to be very attached to the children, often taking over the mothering role and at times showing signs of overpossessiveness. This would fit them in the category of altnistic suicide according to Resnick's (1969) classification, although at times an element of spouse revenge filicide is also found.

Interestingly enough in the cases studied where the actual biological mother committed the murder, only one was very emotionally attached to the children. The other two 
Medea or the mother who kills her children: Some aspects regarding family murder

were overburdened by financial strain and were physically removed from their husbands (one was divorced, and the other was living apart from her husband who was working in the city). It seems as if they could not cope with the strain of being single mothers without the support of their husbands. Their actions would, however, seem to provide evidence for the category altruistic filicide, as the killing of their children and themselves can also be perceived as an attempt to relieve suffering.

In conclusion it does appear that the parent who takes the life of the children is predominantly the 'mother' figure of the family, in that he or she is the adult most closely attached to the children.

In the next section of the article it will be attempted to examine the myth of the mother figure Medea who killed her children, in the light of the above discussion.

\section{MEDEA OR THE MOTHER WHO KILIS HER CHILDREN}

There are two famous versions of the myth of Medea as mentioned in the introduction.

The first version is a tragedy by Euripides produced in 431 B.C. This tragedy focuses on the later portion of the story of Jason and Medea who have fled to Corinth after Medea has, for Jason's sake, murdered his uncle Pelias. Jason, ambitious and weary of his barbarian princess (Medea) has arranged to marry the daughter of Creon, king of Corinth. The desertion and ingratitude of the man she loves rouse the savage in Medea, and she is outspoken in her rage. Creon, fearing her vengeance on himself and his daughter pronounces instant banishment on Medea and her two children. By dissimulation Medea obtains one day's respite and contrives the deaths of Jason's bride and her father. She then kills her own children partly to make Jason childless, and partly because since they now must surely die, it is better they should perish by her hand than by her enemies. Finally taunting Jason in his despair, she escapes to Athens, where she has secured asylum from the ruling king (Harvey, 1980:263-264).

In the version of the Roman philosopher Seneca, the emphasis of the tragedy is slightly different and the children are not banished together with Medea, because Jason's love for them forbids it. Medea thus learns where Jason is vulnerable and kills them to revenge herself on him (Harvey, 1980: 264).

Two elements in these classical works require our attention.

In both Euripides' and Seneca's versions we find the idea of the woman's revenge against a husband who has wronged her. 
In Euripides' version we encounter the idea that as a mother, the murderess has a right to decide the destiny of her children. Since they are meant to die, it is more appropriate that the mother should do this by her own hand (which could be seen as a distorted sense of responsibility).

These two above-mentioned elements of revenge and of the right to control the destiny of one's children, remind us of the two types of filicides classified by Resnick (1969) which were discussed earlier namely, the spouse revenge filicide and the altruistic filicide.

However, the idea of revenge which is of course a strong element in both versions of the tragedy, is only partly relevant to our analysis of modern day family murder.

What really does form an important part of the family murder, especially when the murderer is the parent most emotionally attached to the children, is this sense of distorted responsibility. This distorted responsibility manifests itself in the idea that there is no one else in the world who can look after the child(ren) properly. In the case where the biological mother commits the murder (in spite of not really being close to the children) it nevertheless reflects a distorted sense of what a mother's responsibility implies.

To the person who commits the family murder in this context of irrational 'rationality', this kind of thinking is totally acceptable. The would-be family murderer, like Medea, is faced with what he or she perceives to be 'the end of the world', and death seems to be the only way out.

In the light of this realisation the 'mothering' parent is faced with two terrible alternatives, either suicide which would imply leaving the children to face the problems he or she could not solve as an adult, or to take them with as they would 'die' anyway, either literally as in Medea's case, or figuratively as perceived by the family murderer.

\section{THEORETICAL CONSIDERATIONS}

As is clear from the above discussion it can be concluded that the altruistic aspect of the killing of the children within the context of family murder is an important one. It is thus suggested that the main emphasis should be placed on altruism when examining the phenomenon of the 'mother figure' killing the children. In fact we have seen that this tendency was present even where the biological mothers were not really emotionally close to their children. 
The parent who takes the children's lives, takes the nurturing aspect associated with motherhood to its most absurd and irrational extreme where the belief exists that the children's well-being can only be achieved by ending their lives. This implies a total distortion of the concept of the reality of 'motherhood' and its associated nurturing aspects. As in the case of Medea who was overwhelmed by the betrayal of the husband she loved and thus committed an ultimately irrational act, in the same way the family murderer, who feels abandoned and alone in the world, takes the protecting aspect of parenting to an almost 'psychotic' extreme, in the sense that the protecting aspect becomes totally distorted and out of touch with reality. It almost assumes the dimension of a 'delusion of grandeur' where the parent assumes a godlike position in terms of ultimate control over life and death. We are therefore faced here with a phenomenon which we could term deluded motherhood.

In the case of the father who kills his children this distortion of reality is doubly stronger because the man perceives himself to be the 'mother', taking on the total responsibility for his children's lives.

This phenomenon of 'deluded motherhood' is an extreme example of not being able to let go of one's children. It reflects a feeling that only the parent can look after them properly and a belief that if he or she as parent could not cope with life, the children would also be unable to cope.

From a systemic analysis of the family system involved, one could argue that the murderer-children subsystem becomes closed off in terms of outer boundaries, functioning almost as an independent unit. The murderer probably perceives himself or herself as the pivotal point around which the whole family functions as the spouse is perceived as an outsider to the vital parent-children subsystem, and is also perceived unable to hold the family together. Therefore, when the parent reaches the decision that he or she can no longer cope with the present situation it is not only a decision about control of his or her own life and death, it also becomes (partly as a result of this deluded idea about 'motherhood'), a decision about the children's lives. Beyers $e t$ al. (1992) also comment on the fact that because of the emotionally strong bond that exists between the murderer and the children, divorce is not an option as it would break up this only meaningful relationship. The murderer thus sees the only alternative available in this context, and the only way to save the subsystem from inevitable disaster, as the actual destruction of the existing family system.

\section{CONCLUSION}

These preliminary conclusions represent tentative hypotheses about the phenomenon 
of family murder and one could speculate at length about it. As reflected by all available literature and research on the subject, the answers are still unsatisfactory and most questions remain unanswered.

The aim of this article was to identify a certain recurring phenomenon based on a close analysis of the case studies found in the HSRC report and to highlight a phenomenon which should be perhaps investigated in more detail.

A closed-off murderer-children subsystem was identified where the murderer takes on a 'distorted' mother role and sees the destruction of the whole family system as the ultimate solution to the existing problems.

Parents have to deal with changes in terms of gender roles within the marital subsystem, as well as increasing responsibilities towards their children, both within a larger context of social change. The stress experienced can sometimes escalate to such an extent that past coping mechanisms become obsolete as people desperately try to deal with what is often perceived as a totally hopeless situation. Relationships often become distorted and healthy family functioning becomes impossible. The family murderer experiences this as an impossible situation leaving only one option open, namely the destruction of the family system.

Men and women have experienced many stressful changes in the last decades and have often found themselves isolated with little understanding or support from society for the upheaval it has caused in their lives. People can become isolated even in the family context, which should by definition provide security as well as an opportunity for personal development and growth. When this happens, the isolation becomes total and can lead to a situation of utter desperation which is characteristic of the phenomenon of family murder.

More research should be directed towards the changes which have and are still taking place within families in our society. Especially in the South African context the enormous political and social changes are bound to have an added effect on the stress experienced by individuals and families alike.

Professionals should be aware of the above mentioned factors, should respect the importance of family ties and should be sensitive to the experiences of different individuals.

It still remains a great source of anguish to all professionals involved that constructive ideas on intervention and prevention remain scarce. It is hoped that more discussion of this topic will eventually bring us closer to a solution for this terrible 'Medean 
tragedy' of our time.

\section{BIBLIOGRAPHY}

BEYERS, D., VISSER, M.J. \& MARCHETTI, M.C. 1992. The Family Context: Processes and Interaction in Family Murder. Geneeskunde, 34(9):3-7.

DE JONGH VAN ARKEL, J.T. 1985. Gesinsmoord: 'n pastorale-teologiese perspekticf. South African Joumal of Law and Criminology, 9(2):141-148.

DE JONGH VAN ARKEL, J.T. 1988. Gesinsmoord: 'n toenemende verskynsel. UNISA Bulletin, 13(4):11.

EURIPIDES. 1968. Medea and Other Plays. Harmondsworth : Penguin Books Lid.

HARVEY, P. 1980. The Oxford Companion to Classical Literature. Oxford : Clarendon Press. (10th ed) MARCHETTI, M.C., HAASBROEK, C.P. \& DE JONGH VAN ARKEL, J.T. 1992. A Literature Review on Family Murder. Geneeskunde, 34(8):6-10.

OLIVIER, L., HAASBROEK, C.P., BEYERS, D., DE JONGH VAN ARKEL, J.T., MARCHETTI, M.C., ROOS, J.L., SCHURINK, E.M., SCHURINK, W.J. \& VISSER, M.J. 1991. The Phenomenon of Family Murder in South Africa: An Exploratory Study. Pretoria : HSRC Report ED-8.

RESNICK, PJ. 1969. Child Murder by Parents: A Psychiatric Review of Filicide. American Joumal of Psychiatry, 126(3):73-82. 